\title{
Compatriots into Citizens. Policies and Perceptions of Citizenship Acquisition in Post-Soviet Russia
}

\author{
Marthe Handå Myhre \\ Oslo: Universitetet i Oslo, Det humanistiske fakultet 2018 \\ 192 sider.
}
Omtalt av Marta Bivand Erdal [Forsker 1, Institutt for fredsforskning, marta@, prio.org]

Marthe Handå Myhres doktorgradsavhandling, ved Institutt for litteratur, områdestudier og europeiske språk, Universitet i Oslo, setter søkelyset på grenseoppganger mellom migrant og borger i dagens Russland. Avhandlingens tema er høyaktuelt og viser med all mulig klarhet, hvordan kategoriske skiller mellom «oss» og «de andre» er et universelt fenomen, der parallellene til andre land både i og utenfor Europa er åpenbare. Regulering av medlemsskap i nasjonalstater gjennom statsborgerskapsinstitusjonen, er i Russland, såvel som mange andre steder i sentral- og øst-Europa, et fenomen som er dypt forankret i regionens historie. Her er ikke bare folkeforflytninger, men også tidligere grenseforflytninger relevante.

Gjennom doktorgradsavhandlingens tre artikler, og innledende kapitler, viser Marthe Handå Myhre hvordan russisk statsborgerskapspolitikk kommer fram gjennom såvel lovtekster som gjennom de erfaringer migranter og flyktninger fra Ukraina gjør seg i møte med denne statsborgerskapspolitikken. Det konkrete eksemplet, bosettings programmet for russisktalende fra Russlands nærområder som relativt enkelt gir bosettingstillatelse med muligheter for å søke om statsborgerskap, viser hvordan språklig og (antatt) kulturell likhet, settes høyt av russiske myndigheter. Programmet er ett av flere eksempler på former for organisert og tilrettelagt migrasjon i dette tilfellet i Russland - men også forøvrig i sentral- og øst-Europa, som ikke er spesielt godt kjent utover kretsen som er interessert i regionen spesifikt.

Fokuset på statsborgerskap og migrasjon i dagens Russland begrunnes godt i avhandlingen og er verdt å gjøres eksplisitt: Med tanke på case-valg for en studie av statsborgerskap, nasjon og migrasjon er Russland en særdeles sterk kandidat. Diskusjonene om russisk nasjonal identitet som har vært pågående siden Sovjetunionens fall sentrerer om en dikotomi mellom "oss» og "de andre», der den historiske arven og landets enorme geografiske areal danner viktige forståelsesrammer. Her viser Marthe Handå Myhres arbeid hvordan «post-sovjetiske» migranter-som-blir-borgere styrker Russlands geopolitiske posisjon. Den store innvandringen til Russland, ikke 
minst fra Sentral-Asia, går kanskje under radaren mange steder vest i Europa, men er en viktig økonomisk faktor for mange av migrantenes opprinnelsessteder, såvel som områdene der de bosetter seg i Russland.

Det teoretiske landskapet avhandlingen beveger seg i er tunge samfunnsvitenskapelige spørsmål om forholdet mellom statsborgerskap, medlemskap og stat, og disse knyttes til forståelser av nasjon og etnisitet. Mens mye dreier seg om «oss» og «de andre» skiller som reflekterer en avgrenset gruppetenkning, påpeker Marthe Handhå Myhre, gjennom møysommelig empirisk arbeid, hvordan det finnes grader av oss og de andre. For russiskkyndige er dette kjent, men forskjellen i bruk - og forståelse av - kategorier for nasjonal tilhørighet som «russkije» vs. «rossijane», illustrerer hvordan grenser ikke bare avgrenser, men også gir anledning for grensearbeid fra ulike posisjoner. Forskjellen i kategorisering er knyttet både til bestemte historiske sammenhenger og er avhengig av den gitte politiske kontekst.

Avhandlingens kanskje største styrke er at dens fokus på både statlig regulering av adgang til statsborgerskap og regulering av migrasjon, samt på migranters egne erfaringer med og refleksjoner rundt rådende statsborgerskapspolitikk i Russland. Denne kombinasjonen muliggiør en analyse av forholdet mellom statsborgerskap og medlemsskap, som tar opp i seg både prinsipielle og pragmatiske dimensjoner, fra staten og migrantene. Utgangspunktet i språk- og områdestudier gir Marthe Handå Myhre mulighet til å vise, med stor innsikt og dybde, de ulike rutene som er åpne på veien fra migrant til borger for noen, men ikke andre. Gjennom dette konkretiseres betydningen av historie og (forestilte) slektskapsbånd som svært sentral for forståelser av statsborgerskap og (politisk) medlemsskap i dagens Russland.

Doktorgradsavhandlingen Compatriots into Citizens. Policies and Perceptions of Citizenship Acquisition in Post-Soviet Russia er et viktig forskningsbidrag om migrasjon og statsborgerskap i dagens Russland. Den er i så måte vel så mye et bidrag til migrasjonsstudier som den er til et områdestudier-felt. Avhandlingens empiriske fokus på migrasjon til Russland, og den russiske stats håndtering av migrasjon som fenomen, samt migranters erfaringer av dette, er viktig og ny kanskje særlig for migrasjonsforskere som hverken er interessert i Russland, eller leser russisk. Teoretisk er problemstillingene tett knyttet til spørsmål om nasjon og medlemskap som favner videre enn migrasjonsstudier, og langt inn i kjernespørsmål på tvers av fag som statsvitenskap, sosiologi, eller antropologi og geografi. Gjennom artikler blant annet publisert i Nationalities Papers og Russian Review, viser Marthe Handå Myhre en evne til nettopp å kommunisere tverrfaglig med sine teoretiske og empiriske innsikter.

At også Russland har fokus på statsborgerskapsed som et grep i sin statsborgerskapspolitikk, er et interessant tegn på at statsborgerskapspolitikken på tvers av land som ofte ser på seg selv som nokså ulike, kanskje er mer konvergerende enn antatt. Denne veldig konkrete innsikten fra Marthe Handå Myhres avhandling er kun én av flere som illustrerer hennes arbeids relevans - langt utenfor kretsen av interesserte i den russiske konteksten spesifikt. Samtidig kan avhandlingen også være en nyttig påminnelse om at den russiske konteksten - ikke minst med tanke på migrasjon og statsborgerskapsspørsmål - er høyrelevant å forstå bedre. 